\title{
RELATIONSHIP BETWEEN HOW TO LEARN, MATHEMATIC COMMUNICATION, AND LEARNING FACILITIES WITH RESULTS OF MATHEMATICS STUDENTS IN SMP MUHAMMADIYAH 4 YOGYAKARTA
}

\author{
Desta Senja Nuansa ${ }^{a}$, Uswatun Khasanah ${ }^{b}$ \\ Program Studi Pendidikan Matematika Universitas Ahmad Dahlan \\ Jalan Ring Road Selatan, Tamanan, Banguntapan, Bantul Yogyakarta \\ adestasenja@gmail.com, ${ }^{\text {buswatun.khasanah2@pmat.uad.ac.id }}$
}

\begin{abstract}
Student learning outcomes are determined by many factors. How to learn, mathematical communication and learning tools are several factors related to student learning outcomes. This study aims to determine whether or not there is a positive and significant relationship between learning methods, mathematical communication, and learning tools with mathematics learning outcomes for students of class VIII of SMP Muhammadiyah 4 Yogyakarta odd semester 2016/2017 academic year. The population in this study were eighth-grade students of SMP Muhammadiyah 4 Yogyakarta 2016/2017 academic year, consisting of classes VIIIA, VIIIB, VIIIC, VIIID totaling 104 students. Samples were taken from class VIIIB as a class of research samples with random sampling techniques to the class. Data collection techniques used a questionnaire method to obtain data on learning methods and learning tools, as well as test methods to obtain mathematical communication data and mathematics learning outcomes. Research instrument test: validity test, different power test, and reliability test. Analysis prerequisite tests include normality test, linearity test, and independence test. Data analysis uses product moment analysis and multiple linear regression analysis. The results showed that there was a positive and significant relationship between ways of learning, mathematical communication, and learning facilities with mathematics learning outcomes of VIII grade students of SMP Muhammadiyah 4 Yogyakarta Odd Semester 2016/2017 Academic Year. This was indicated by $F_{\text {count }}>F_{\text {table }}$ that is 4,692 $>3,05$ with $\mathrm{R}=0,6252$ and $\mathrm{R}^{2}=0,391$ with $\hat{Y}=14,538+0,209 X_{1}+0,156 X_{2}+0,316 X_{3}$, with $\mathrm{SR} \mathrm{X}_{1}=35,330 \%, \mathrm{SR} \mathrm{X}_{2}=41,896 \%$ and $\mathrm{SR} \mathrm{X}_{3}=22,774 \%$, SE $\mathrm{X}_{1}=13,786 \%$, SE $\mathrm{X}_{2}=$ $13,786 \%$ and $\mathrm{SE} \mathrm{X}_{3}=16,348 \%$.
\end{abstract}

Keywords: How to Learn, Mathematical Communication, and Learning Tools, Learning Outcomes of Mathematics.

\section{INTRODUCTION}

Good quality education can be seen among others from the teaching and learning process that occurs as well as the learning outcomes achieved by students. Educational goals are said to be achieved if student learning outcomes experience growth and improvement. As for what is meant by learning outcomes are the results of learning efforts implemented by students. Informal education is always followed by measurement and assessment, as well as learning outcomes can be seen in the position of students who are fast, moderate or slow in receiving subject matter. Receive subject matter. In the learning process, elements of the learning process play an important role. The core of educational activities is teaching and learning activities. The success of students in attending educational programs in schools is seen based on the results of their learning. Learning outcomes are the maximum benchmarks achieved by students after making the learning process. According to Subini, Nini (2012: 85) "Many things can affect one's learning process, both from within (internal), outside (external), as well as learning tendency factors". Internal factors are factors that exist in individuals who are doing learning, including ways of learning and mathematical communication. External factors are external factors which include learning tools.

From interviews with a number of eighth-grade students of SMP Muhammadiyah 4 Yogyakarta, students still rarely study at home. Some students study at home if there are assignments from school or if they are going to face an exam. This indicates students have a way of learning that is less efficient. In addition, from the results of interviews with mathematics teachers in grade VIII, SMP Muhammadiyah 4 Yogyakarta in general students' mathematical communication skills are still low, this 
is evidenced by the ability of students to convey mathematical ideas/ideas both verbally and in writing from contextual problems (story problems) still less. Most students find it difficult to change a contextual problem into a mathematical sentence. Based on the results of interviews with a number of eighth-grade students at Muhammadiyah 4 Junior High School, Yogyakarta, not a few students complained and said that they still had difficulty learning mathematics and considered mathematics as the most difficult subject compared with other subjects. Difficulties of students in learning mathematics by itself make students not interested in mathematics that results in low student learning outcomes.

Based on observations obtained information that students still do not optimize the use of learning facilities at home, this is evidenced by the students who do not use the facilities provided by parents. Based on the final semester test scores (UAS) of VIII grade students of SMP Muhammadiyah 4 Yogyakarta in the 2016/2017 school year, it is known that the number of students less than the Minimum Mastery Criteria (KKM) of 101 students out of 102 students has not yet reached the KKM value of 70 in subjects mathematics applied in school. This shows that students 'mathematics learning outcomes are still low. Thus, based on the above problems, researchers are encouraged to express the relationship between ways of learning, students' mathematical communication and learning tools with mathematics learning outcomes. This is intended to obtain information about how to learn, students' mathematical communication and learning tools in relation to mathematics learning outcomes. The aim of this research is to find out whether there is a positive and significant relationship between learning methods, mathematical communication, and learning tools with mathematics learning outcomes for students of class VIII of SMP Muhammadiyah 4 Yogyakarta 2016/2017 Academic Year.

\section{THEORY}

According to Hamalik, Oemar (2005: 30) how to learn is learning activities carried out in learning something, that is, activities that should be carried out in certain learning situations. According to Suderajat, Hari (2004: 44) Communication skills play an important role in helping students build relationships between informal and intuitive aspects with abstract language and symbols of mathematical language, as well as between physical, pictorial, graphic, symbolic and verbal, with a mental picture of mathematical ideas. All learning activities in the form of exploration, explaining, investigating, investigating, outlining, establishing a decision, encouraging students in developing communication skills. Means of learning according to Roestiyah (2004: 166) are learning tools needed in the learning process so that the achievement of learning goals can run smoothly, orderly, effectively and efficiently.

\section{METHODS}

The type of research used is as follows:

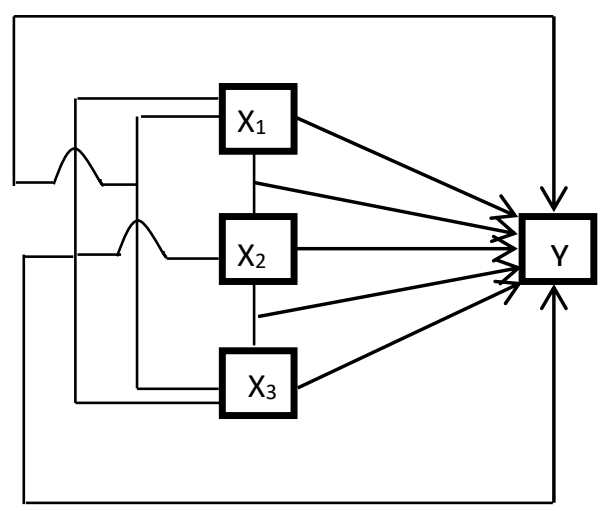

Picture I. Multiple paradigms with three independent variables. 
Information:

$\mathrm{X}_{1} \quad=$ How to learn

$\mathrm{X}_{2} \quad=$ Mathematical Communication

$\mathrm{X}_{3} \quad=$ Means of Learning

$\mathrm{Y} \quad=$ Mathematics Learning Outcomes

The study was conducted at SMP Muhammadiyah 4 Yogyakarta. The study was conducted in the odd semester of the 2016/2017 school year. The population in this study were eighth-grade students of SMP Muhammadiyah 4 Yogyakarta Odd Semester 2016/2017 Academic Year consisting of 4 classes, namely class VIII A, VIIIB, VIIIC, VIII D with a total number of students 104 students. In this study the sampling was done using random sampling techniques, the class is taken as a research sample was class VIII B with 26 students. As for the techniques used to collect data in this study were questionnaires and tests. Before being used to reveal the actual data, the instrument was tested in the pilot class with the aim of knowing the validity and reliability of the instrument or in other words to identify problems that were weak or flawed. According to Arikunto, Suharsimi (2012: 85) a test is said to have validity if the results are in accordance with the criteria, in the sense of having parallels between the results of the tests with the criteria.

The analysis test used in this study is a prerequisite test in the form of a normality test, an independent test and a linearity test, and a hypothesis test. To test the hypothesis, it uses simple linear regression analysis and multiple linear regression tests. The normality test, independent test and linearity test are as follows:

a. Normality test

A normality test is used to determine whether the data used is normally distributed or not. The formula used is the Chi-Squared formula.

Table 1. Summary of Normality Test Results

\begin{tabular}{ccccc}
\hline Variable & $\chi_{\text {count }}^{2}$ & $\chi_{\text {table }}^{2}$ & $\mathrm{df}$ & Conclusion \\
\hline $\mathrm{X}_{1}$ and $\mathrm{X}_{2}$ & 22,604 & 37,652 & 25 & Independent \\
$\mathrm{X}_{1}$ and $\mathrm{X}_{3}$ & 35,064 & 37,652 & 25 & Independent \\
$\mathrm{X}_{2}$ and $\mathrm{X}_{3}$ & 22,192 & 37,652 & 25 & Independent \\
\hline
\end{tabular}

b. Independent Test

The independent test is used to determine the presence or absence of a relationship between the independent variables learning ways (X1) with mathematical communication (X2), the relationship between independent variables learning ways (X1) with learning tools (X3), and the relationship between mathematical communication independent variables (X2)) with learning tools (X3), namely by using the Chi-Square formula.

Table 2. Summary of Independent Test Results

\begin{tabular}{ccccc}
\hline Variable & $\chi_{\text {count }}^{2}$ & $\chi_{\text {table }}^{2}$ & $\mathrm{df}$ & Conclusion \\
\hline How to Study $(\mathrm{X} 1)$ & 1,806 & 5,992 & 2 & Normal \\
Mathematical Communication $\left(\mathrm{X}_{2}\right)$ & 0,487 & 5,992 & 2 & Normal \\
Learning Facilities $\left(\mathrm{X}_{3}\right)$ & 2,219 & 7,815 & 3 & Normal \\
Mathematics learning outcomes $(\mathrm{Y})$ & 3,169 & 5,992 & 2 & Normal \\
\hline
\end{tabular}

c. Linearity Test

Linearity Test is used to determine the relationship between independent variables and dependent variables are linear or not. The test statistic used is the F Test.

Table 3. Summary of Linear Test Results

\begin{tabular}{cccc}
\hline Variable & $F_{\text {count }}$ & $F_{\text {table }}$ & Conclusion \\
\hline $\mathrm{X}_{1}$ to $\mathrm{Y}$ & 1,063 & 3,20 & Linear \\
$\mathrm{X}_{2}$ to $\mathrm{Y}$ & 1,002 & 2,83 & Linear \\
$\mathrm{X}_{3}$ to $\mathrm{Y}$ & 3,721 & 3,90 & Linear \\
\hline
\end{tabular}




\section{RESULTS AND DISCUSSION}

Data on how students learn was obtained from the instrument scores given to 26 students in the number of 25 statement items. Then obtained the highest score of 109 and the lowest score of 56. Mathematical communication data was obtained from the instrument scores given to 26 students in a number of 3 questions. Then obtained the highest value of 100 and the lowest value of 0 . Data for learning tools were obtained from the scores of the instruments given to 26 students totaling 25 statements. Then obtained the highest score of 119 and the lowest score of 80. Mathematics learning outcomes data obtained from the instrument scores given to 26 students a total of 20 questions. Then obtained the highest value of 95 and the lowest value of 55 .

With a double analysis obtained the value of the correlation coefficient $(\mathrm{R})$ between learning, mathematical communication and learning tools with mathematics learning outcomes of 0.632 . Furthermore, in testing the significance of the correlation coefficient by using the F-test obtained $\boldsymbol{F}_{\text {count }}=4,886$ while $F_{\text {table }}=3,05$ at a significant level of $5 \%$ and $\mathrm{v}_{1}=3$ and $\mathrm{v} 2=\mathrm{n}-\mathrm{m}-1=$ 26-3-1 = 22 so that it is obtained $\boldsymbol{F}_{\text {count }}>F_{\text {table }}$.

The things that have been explained above, can be explained through linear relationships $\hat{Y}=$ $11,094+0,2092 X_{1}+0,1547 X_{2}+0,3501 X_{3}$. This means an increase in one unit $\left(X_{1}\right)$ results in 0.209 increase in $\mathrm{Y}$, increase in one unit $\left(\mathrm{X}_{2}\right)$ results in 0.155 increase in $\mathrm{Y}$, and an increase in one unit $\left(\mathrm{X}_{3}\right)$ results in 0,350 increase in $\mathrm{Y}$, in other words, if the relationship between learning, mathematical communication, and learning facilities is increasingly well, then student mathematics learning outcomes will increase. Student mathematics learning outcomes are influenced by learning methods, mathematical communication and learning facilities by $39.1 \%$ while $60.9 \%$ are influenced by other factors not discussed in this study. Of the three variables in this study, the greatest effective contribution was the mathematical communication variable $\left(\mathrm{X}_{2}\right)$.

After learning that learning methods, mathematical communication, and learning tools have a positive and significant effect on mathematics learning outcomes, this means that the increase and decrease in student mathematics learning outcomes are related to learning, mathematical communication, and learning tools. Therefore it is expected that various parties can optimize their role in improving student mathematics learning outcomes.

\section{CONCLUSION}

Based on the results of the research and discussion above, the conclusion that can be drawn is that there is a positive and significant relationship between ways of learning, mathematical communication and learning tools with mathematics learning outcomes of VIII grade students of SMP Muhammadiyah 4 Yogyakarta odd semester 2016/2017 academic year.

\section{REFERENCES}

Arikunto, Suharsimi. 2012. Dasar-dasar Evaluasi Pendidikan. Jakarta: Bumi Aksara.

Hamalik, Oemar. 2005. Metoda Belajar dan Kesulitan-Kesulitan Belajar. Bandung: Tarsito.

Roestiyah. 2004. Interaksi dan Motivasi Belajar Mengajar. Jakarta: PT. Raja Grafindo Persada.

Subini, Nini. 2012. Psikologi Pembelajaran. Yogyakarta: Mentari Pustaka.

Suderadjat, Hari. 2004. Implementasi Kurikulum Berbasis Kompetensi (KBK). Bandung: CV. Cipta Cekas Grafika. 